УдК 342.951:355.097.2

DOI https://doi.org/10.32850/sulj.2019.3-22

\title{
ПРОБЛЕМАТИКА НАЦІОНАЛЬНОЇ ГВАРДІЇ ПІД ЧАС ПАТРУЛЮВАННЯ МІСТА
}

Томіна В. Ю., Сірко В. С.

У науковій статті розглядаються питання взаємодіі Національної гвардії України та Національної поліції України. На підставі аналізу законодавства України зроблено висновок про проблематику Національної гвардії України під час патрулювання міста.

В умовах глобалізованого світу і динамічних якісних змін у службово-бойовій та оперативно-службовій діяльності Національної гвардіі України актуалізовано протиріччя між потребою держави в офіцерських кадрах, здатних удосконалювати свою професійну підготовку, самостійно приймати обгрунтовані рішення в процесі військово-професійної діяльності, і відсутністю фундаментальних і прикладних наукових досліджень професійної підготовки в теорії і практиці вищої військової освіти.

Ключові слова: підготовка, професійна підготовка офіцерів, Національна гвардія, офіцери Національної гвардії.

В научной статье рассматриваются вопросы взаимодействия Национальной гвардии Украины и Национальной полиции Украины. На основании анализа законодательства Украины сделан вывод о проблематике Начиональной гвардии Украины при патрулировании города.

В условиях глобализирующегося мира и динамических качественных изменений в служебно-боевой и оперативно-служебной деятельности Национальной гвардии Украины актуализировано противоречие между потребностью государства в офицерских кадрах, способных совершенствовать свою профессиональную подготовку, самостоятельно принимать обоснованные решения в процессе военно-профессиональной деятельности, и отсутствием фундаментальных и прикладных научных исследований профессиональной подготовки в теории и практике высшего военного образования.

Ключевые слова: подготовка, профессиональная подготовка офицеров, Национальная гвардия, офицеры Национальной гвардии.

The scientific article deals with the interaction of the National Guard of Ukraine and the National Police of Ukraine. On the basis of the analysis of the legislation of Ukraine the conclusion was made about the problems of the National Guard of Ukraine during patrolling the city.

The history of the troops of the National Guard of Ukraine dates back to 1991. One of the reasons for the creation in 1991, on the basis of units of the Internal Guard of the Ministry of Internal Affairs of the USSR, was the need to have military units in case of refusal of the Armed Forces to swear allegiance to the Ukrainian people. Interestingly, participation in public order was added to the National Guard only in 1993, although in Soviet times the Internal Troops, among other things, patrolled cities and dispersed demonstrations.

In the conditions of the globalized world and dynamic qualitative changes in the service, combat and operational activity of the National Guard of Ukraine, the contradictions between the need of the state in officer cadres capable of improving their professional training, making informed decisions in the process of military and professional activity are actualized, applied research of vocational training in the theory and practice of higher military education.

After the victory of the Revolution of Dignity, the Verkhovna Rada on March, 13 in 2014 less than for a half a hour accepted for basis and on the whole the draft of Law "On the National Guard of Ukraine" [3], as a result of which it developed the Internal Base of the National Guard of Ukraine. Presently National Guard of Ukraine counts 50 thousands of servicemen, but to patrolling about 2 thousands are attracted only. Patrols of the National Guard of Ukraine, as well as before, during duties operatively submit the leader of organ of Police, on territory of maintenance of which they carry service. From August, 1 in 2019 the independent patrolling began by National Guardsmen, which is carried out with participation of the Police.

Two years ago, a bill No. 6556 was introduced to parliament, which provided for the approaching of the National Guard of Ukraine to Police officers. The initiative met with resistance from experts and human rights activists and was sent to the dustbin of history. Experts explain the necessity of the bill simply: in 2015, the National Guardsmen were given certain functions, but they were not given sufficient powers to perform them qualitatively.

The National Guard of Ukraine should support the functioning of law enforcement agencies. The central functions of the National Guard of Ukraine are the separate rule of law and the protection of the indigenous borders, which correspond to terrorist activity. One of the main tasks of the National Guard is to protect strategic infrastructure - airports, stadiums (during these or mass events), diplomatic agents, security services, or special crossings of convicts.

On August 1, 2019, military servicemen of the National Guard are engaged to strengthen public order, to respond promptly to reports of criminal offenses, to prevent destabilization of the operational situation, to commit illegal actions in the territory of our country. During patrolling of cities, servicemen of the National Guard of Ukraine are obliged to:

1) to provide protection and protection of life, rights, freedoms and legitimate interests of citizens, society and the state against criminal and other unlawful encroachments;

2) to take part in ensuring public safety and public order, including during meetings, rallies, street campaigns, demonstrations, other mass events;

3) to take measures aimed at prevention, detection of criminal (administrative) offenses;

4) to provide protection of public authorities, implementation of measures of state protection of public authorities and officials, as well as to participate in the protection of public order during official visits and other events with the participation of officials of Ukraine and foreign states subject to state protection in the territory Ukraine;

5) perform the tasks of territorial defense [3].

Key words: training, officer training, National Guard, National Guard officers. 
Постановка проблеми. В умовах глобалізованого світу і динамічних якісних змін у службово-бойовій і оперативно-службовій діяльності Національної гвардії України актуалізовано протиріччя між потребою держави в офіцерських кадрах, здатних удосконалювати свою професійну підготовку, самостійно приймати обґрунтовані рішення у процесі військово-професійної діяльності, і відсутністю фундаментальних і прикладних наукових досліджень професійної підготовки в теорії і практиці вищої військової освіти.

Підсилює назване протиріччя фактор консервативності системи підготовки офіцерів для Національної гвардії порівняно зі стрімко змінюваними потребами освітнього ринку і викликами глобалізації.

У зв'язку з цим завдання досягнення відповідності рівня військово-професійної освіти імперативів розвитку суспільства, силових структур України і всієї системи вищої освіти країни стає стратегічним і вимагає науково-міждисциплінарного дослідницького пошуку з визначення концептуальних підходів до управління якістю підготовки офіцерів для Національної гвардії, до його науково-методичного забезпечення та технологізації [2].

Аналіз публікацій та останніх досліджень. Безпосередньо діяльність Національної поліції України та Національної гвардії України у сфері охорони громадського порядку ставала об'єктом досліджень А.В. Басова, Є.В. Білозьорова, С.Г. Брателя, О.К. Волоха, А.П. Головіна, В.А. Грабельникова, О.В. Джафарової, А.В. Жбанчик, І.М. Копотуна, О.В. Кривенка, С.О. Кузніченка, О.М. Музичука, Ю.С. Небеського, А.С. Поклонського, А.В. Серьогіна, О.І. Ульянова, Д.П. Цвігуна, В.М. Цикалевича, С.О. Шатрави та інших учених.

Метою статті $\epsilon$ з'ясування актуальних питань взаємодії Національної гвардії України та Національної поліції України на підставі аналізу норм законодавства України та практики його застосування.

Підготовка офіцерів для Національної гвардії України нині здійснюється на основі системно-комплексного підходу до забезпечення інноваційного розвитку та конкурентоспроможності ВВНЗ та з урахуванням багатогранної сутності професійної підготовки, процесів, що протікають у зовнішньому середовищі, а також управління якістю освіти та виховання суб'єктів військово-освітнього процесу.

Ці та низка інших, більш приватних факторів призводять до підвищення ролі професійної підготовки в суспільстві і державі [3]. Для України з урахуванням соціально-політичних умов, в яких нині перебуває наша держава, основним напрямом зовнішньої політики $\epsilon$ захист національних інтересів і забезпечення національної безпеки. Здійснюється вона способами застосування методів правового, військового, політичного і найбільш популярного нині інформаційного впливу з метою створення протидії агресору, що знаходиться як за територією України, так і всередині країни. Зберегти наявний конституційний лад держави, захистити суверенітет країни, забезпечити дотримання прав і свобод громадян, виконати соціальні гарантії - саме ці національні інтереси виражають основну політичну позицію нашої держави [1].

Історія військ Національної гвардії України бере свій початок ще з 1991 р. Однією з причин створення в 1991 р. на базі частин Внутрішніх військ МВС СРСР Національної гвардії була потреба мати військові фор- мування на випадок відмови Збройних сил присягнути на вірність українському народові. Цікаво, що участь в охороні громадського порядку додали до повноважень Нацгвардії тільки в 1993 р, хоча за радянських часів Внутрішні війська, крім іншого, патрулювали міста і розганяли демонстрації.

У грудні 1999-го, після повторного обрання Леоніда Кучми Президентом України, депутати Верховної Ради для приведення у відповідність до Конституції і щоб уникнути дублювання повноважень прийняли закон про розформування Національної гвардії України з передачею іï частин і підрозділів Внутрішніх військ МВС і Збройним силам. Далі внутрішні війська діяли паралельно з Нацгвардією, але виконували обмежені функції охорони важливих об'єктів, а з 1995 р. їх залучали також до охорони громадського порядку. Під час Революції Гідності Внутрішні війська разом з міліціонерами «Беркута» брали участь у силовому протистоянні з протестуючими.

Після перемоги Революції Гідності Верховна Рада 13 березня 2014 р. менше ніж за півгодини прийняла за основу і в цілому проєкт Закону «Про Національну гвардію України» [3], яким розформувала Внутрішні війська МВСУ, створивши на їх базі Національну гвардію. Нині Нацгвардія налічує 50 тис. військовослужбовців, але до патрулювання залучені тільки близько 2 тис. Патрулі Національної гвардії України, як і раніше, під час чергувань оперативно підпорядковуються керівнику органу поліції, на території обслуговування якого вони несуть службу. 31 серпня 2019 р. розпочалося самостійне патрулювання нацгвардійцями міст, що здійснюється за участю поліцейських.

Військовослужбовці під час патрулювання можуть застосовувати поліцейські заходи, а також спецзасоби і зброю відповідно до Закону України «Про Національну поліцію» [4]. Водночас гвардійці не зупиняють транспортні засоби за порушення Правил дорожнього руху і не можуть самостійно притягнути порушників до адміністративної або кримінальної відповідальності. Тому під час виявлення порушників патрулі Нацгвардії для подальших дій змушені залучати поліцейських.

Два роки тому до парламенту було подано законопроєкт № 6556, що передбачав наближення повноважень Національної гвардії України до поліцейських. Ініціатива зустріла опір з боку експертів і правозахисників і була відправлена на смітник історії. Експерти необхідність у законопроєкті пояснюють просто: у 2015 р. нацгвардійців наділили певними функціями, але для якісного їх виконання не дали достатніх повноважень.

Підсумовуючи, зазначимо, що Національна гвардія України - це військове формування з функціями правоохоронних органів. Серед основних функцій НГУ - забезпечення правопорядку й охорона державного кордону, припинення терористичної діяльності тощо. Одним з основних обов'язків нацгвардійців $\epsilon$ захист стратегічних об'єктів інфраструктури - аеропортів, стадіонів (під час важливих або масових подій), дипломатичних представництв, охорона спеціальних вантажів або забезпечення конвоювання засуджених.

Відповідно до пункту 1 частини 1 статті 13 Закону України «Про Національну гвардію України» [3] військовослужбовці Нацгвардії під час залучення до виконання завдань з охорони громадського порядку мають право здійснювати превентивні і поліцейські заходи примусу 
відповідно до Закону «Про Національну поліції» [4]. Зокрема, в статті 31 Закону передбачено такий перелік превентивних заходів, як:

- перевірка документів особи;

опитування особи;

- поверхнева перевірка й огляд;

- зупинка транспортного засобу;

- вимога залишити місце й обмеження доступу до певної території;

- обмеження пересування особи, транспортного

засобу або фактичного володіння річчю;

- проникнення в житло або інше володіння особи;

перевірка дотримання вимог дозвільної системи

органів внутрішніх справ;

- застосування технічних приладів та технічних засобів, що мають функції фото- і кінозйомки, відеозапису, засобів фото- і кінозйомки, відеозапису;

- перевірка дотримання обмежень, встановлених законом щодо осіб, які перебувають під адміністративним наглядом, і інших категорій осіб;

- поліцейське піклування.

Стаття 42 Закону «Про Національну поліцію» [3] визначає конкретний перелік поліцейських заходів примусу: фізичний вплив (сила), застосування спеціальних засобів і застосування вогнепальної зброї.

31 серпня 2019 року з метою посилення заходів з охорони громадського порядку, оперативного реагування на повідомлення про кримінальні правопорушення, недопущення дестабілізації оперативної обстановки, вчинення протиправних дій на території нашої держави до несення служби в складі самостійних нарядів залучено військовослужбовців Національної гвардії України. Здійснюючи патрулювання міст, військовослужбовці Національної гвардії України для забезпечення безпеки громадян відповідно до Закону України «Про Національну гвардію України» зобов’язані:

1) забезпечувати захист та охорону життя, прав, свобод і законних інтересів громадян, суспільства і держави від злочинних та інших протиправних посягань;

2) брати участь у забезпеченні громадської безпеки та охороні громадського порядку, у тому числі під час проведення зборів, мітингів, вуличних походів, демонстрацій, інших масових заходів;

3) вживати заходів, спрямованих на запобігання, виявлення кримінальних (адміністративних) правопорушень;

4) забезпечувати охорону органів державної влади, здійснення заходів державної охорони органів державної влади та посадових осіб, а також брати участь в охороні громадського порядку під час офіційних візитів та інших заходів за участю посадових осіб України та іноземних держав, щодо яких здійснюється державна охорона на території України;

5) виконувати завдання територіальної оборони та ін. [3].

Незважаючи на наявну нормативно-правову базу, що регулює діяльність військ Національної гвардії України, справжньою проблемою $є$ персональна ідентифікація, адже у військовослужбовців НГУ посвідчень немає, у них тільки військові квитки в формі книжечки, які навряд чи треба показувати кому-небудь у воюючій країні.

у Нацгвардії після наполегливих вимог експертного співтовариства було впроваджено використання нагрудних жетонів з номерами і бодікамерами, але i ïх носять не всі, а самі жетони і камери до сих пір не передбачені законодавством і не мають належного регулювання.

Висновки. В умовах проведення реформування військ Національної гвардії України мають бути враховані всі особливості професійної підготовки кадрового офіцера [5]. Необхідне проведення додаткових досліджень і виділення теоретичних аспектів у програмі професійної підготовки офіцерських кадрів з обов'язковим виявленням критеріїв ефективності її управління. Слід постійно удосконалювати практичні навички особового складу, технічні можливості засобів, які застосовуються Національною гвардією України та Національною поліцією України для виконання поставлених перед ними завдань як окремо, так і під час взаємодії один з одним.

\section{Література}

1. Бухун А.Г. Розвиток громадянської компетентності майбутніх офіцерів Національної гвардії України у процесі професійної підготовки : автореф. дис... канд. пед. наук : 13.00.04. Полтав. нац. пед. ун-т імені В.Г. Короленка. Полтава. 2017. 20 с.

2. Міршук О.Є. Застосування компетентнісного підходу в підготовці майбутніх офіцерів Національної гвардії України. Проблеми інженерно-педагогічної освіти. 2017. № 5. С. 56-57.

3. Про Національну гвардію України : Закон України. Відомості Верховної Ради (ВВР), 2014, № 17, ст. 594. URL: https://zakon.rada.gov.ua/laws/show/876-18.

4. Про Національну поліцію : Закон України. Відомості Верховної Ради (ВВР), 2015, № 40-41, ст. 379. URL: https://zakon.rada.gov.ua/laws/show/580-19.

5. Турчинов А. Професійна підготовка майбутніх офіцерів Національної гвардії до застосування здоров'язбережувальних технологій у контексті компетентнісного підходу. Вісник Харківського національного університету імені В.Н. Каразіна. Серія «Валеологія: сучасність і майбутнє». 2015. № (1139), 107. URL: https://periodicals.karazin.ua/ valeology/article/view/3835.

Томіна В. Ю., кандидат юридичних наук, доцент кафедри адміністративного права та адміністративного процесу

Одеського державного університету внутрішніх справ

Сірко В. С., кандидат юридичних наук, викладач кафедри адміністративного права та адміністративного процесу

одеського державного університету внутрішніх справ 